\title{
Review Article \\ Self-Directed Learning: A Core Concept in Adult Education
}

\author{
Svein Loeng \\ Nord University, Nord University Business School, Stjørdal, Norway \\ Correspondence should be addressed to Svein Loeng; svein.loeng@nord.no
}

Received 22 October 2019; Revised 19 June 2020; Accepted 3 August 2020; Published 28 August 2020

Academic Editor: Paul S. Szalay

Copyright $(2020$ Svein Loeng. This is an open access article distributed under the Creative Commons Attribution License, which permits unrestricted use, distribution, and reproduction in any medium, provided the original work is properly cited.

In adult education, the concept of self-directed learning has great importance. This term arose in the field of adult education in the 1970 s and is still a widely used term in the field. Annual symposiums have been held by the International Society for Self-Directed Learning since 1986, dedicated to the promotion of self-directed learning. The society also publishes an international journal of self-directed learning. A term of more recent origin is self-regulation, used by some authors sometimes interchangeably with selfdirection. This review article focuses on the term self-directed learning, which is the term most frequently used in adult education. Many consider the tendency for self-direction to be a fundamental difference between children and adults in a learning situation. This article deals with some factors that affect the understanding of self-directed learning. At the beginning is given a short case story and an account for different perceptions of self-directed learning. This is followed by a clarification of different aspects of selfdirected learning, such as why it is advisable, what affects the tendency to self-directed learning, and if self-direction is essentially innate or learned. The situational aspect is dealt with separately as a relatively self-contained aspect of self-directed learning. The presentation is based on a literature study.

\section{Introduction}

The concept of self-directed learning has been present since my first contact with the field of adult education in the mid1970s. To me, self-directed learning has always been there like a mantra in the field of adult education, showing up in literature and professional converse and debate. Despite this extensive focus in certain fora, I rarely met a learning situation where this approach was systematically used in practice. My experience tells me that self-directed learning has been a concept present in theory, discussions, and exchange of views, but seldom systematically put to practice in adult education.

For the last three decades, I have held a position in higher education. In this field, a challenge is how to design appropriate educational programs to increase student activity and student responsibility concerning their own learning. From my point of view, the situation in higher education is also an obvious reason for increased focus on self-directed learning. Research in the field of self-directed learning may form a useful reflection basis for this transformation and provide a good basis for constructive planning of student active learning. The field of higher education requires a transformation from the authoritative role of the educator into the educator as a facilitator of learning. Self-directed learning should be a well-suited reflection basis for this shift.

In my opinion, an essential condition for practical use of self-directed learning is to clarify all aspects of the concept, so that practice is not based on a limited understanding. The purpose of this article is not to locate all relevant literature related to self-directed learning but to give a basic understanding of the field based on essential written material. This article is a narrative review based on secondary sources which fit for the purpose of clarifying the different aspects of self-directed learning. The main text section is broken down to subparts showing different aspects considered central to the field of self-directed learning. The intention is to account for these aspects in a unified presentation, to provide a quick overview.

\section{Self-Directed Learning- A Short Case Story}

The principle of self-direction can be dated long back to England in the 1800s, where terms such as self-help, self- 
improvement, and self-education were used ([1], p. 46). However, there are obvious reasons to date the scholarly study of self-directed learning back to the beginning of the 1960s. In 1961, Cyril Houle published his book The Inquiring Mind [2]. This book made visible self-directed learning as an important part of adult learning [3]. Houle's intention was probably not to influence the study and practice of selfdirected learning, but his contribution to the area is substantial. Houle did not often use the term self-directed learning, but through his definition, he helped to create space for self-directed learning as a legitimate form of adult education, Brockett and Donaghy state [3]. In his definition of adult learning, he did not presuppose an educational agent to whom the learner should relate to. In Houle's view, individuals can learn alone, in groups, or institutions. This understanding cleared the way for the term self-directed learning. Houle is also linked to self-directed learning through two of his doctoral graduates, Allen Tough and Malcolm Knowles.

Tough's work on self-directed learning was directly influenced by his study with Houle [3].

Tough was also the first one to give a comprehensive description of self-directed learning [4, 5]. He concluded that adults spend a remarkable amount of time on what he called learning projects for the purpose of acquiring and maintaining specific characteristics and skills or changing in one way or another ([6], p. 250). The learning can be performed through reading, listening, observation, course participation, reflection, exercise, or otherwise.

Tough's research on self-directed learning occurred at about the same time as Knowles introduced his andragogy in the book The Modern Practice of Adult Education [7]. In the mid-1970s, Knowles also published a book on self-directed learning [8]. Eduard Lindeman was one of Knowles's greatest inspirers and an early contributor to the field of adult learning. Lindeman hardly used the term self-directed learning, but his works dealt with problems relevant to the field of self-direction. This citation from the 1920 s denounces a basic attitude in his writings: "We live in freedom when we are conscious of a degree of self-direction proportionate to our capacities" ([9], p. 79).

In the 1980s, Candy [10] observed that the notion of selfdirection had attained something of a cult status in the literature of adult education.

\section{What Is Self-Directed Learning?}

Self-directed learning is clearly a multifaceted concept that should not be approached through one perspective. According to Kerka [11], the biggest misconception may be in trying to capture the essence of self-directed learning in a single definition. Van der Walt [12] also points to the terminological confusion regarding this concept, which has led to communication difficulties about the subject of self-directed learning. Van der Walt concludes that researchers in the field of self-directed learning have two options. One is to continue the terminological confusion by defining their understanding of the concept, or, as a second option, they can depart their research from the original definition of self- directed learning provided by Knowles and his colleagues ([12], p. 16). In the following, some notions of the self-directed learning concept are accounted for.

Self-directed learning entails individuals taking initiative and responsibility for their own learning. You are free to set goals and define what is worth learning. Self-directed learning can take place both inside and outside of formal educational institutions. When teachers are involved, they should be facilitators of learning, not transmitters. What is common to most conceptualizations, according to Garrison [13], is the notion of some personal control over either or both the planning (goals) and the management (support) of the learning experience.

Garrison [14] also accentuates that the ultimate goal of self-directed learning is not necessarily fully autonomous learning because it is a matter of degree. Self-directed learning does not entirely depend on the opportunity but also the ability to make learning decisions. Therefore, according to Garrison, in a formal learning situation, it should be seen as a collaborative process between the teacher and the learner. Seen from a critical point of view, it is incomplete to reduce self-direction to a question of external control. "We live interdependently and knowledge is socially determined" ([14], p. 141).

Brookfield [15] also criticizes self-directed learning for ignoring social context by focusing on the individual, isolated learner and stresses the social construction of knowledge and the social context of learning. Merriam and Caffarella [16] call for a wider recognition of the interdependent and collaborative aspects of self-directed learning. O'Donnell [17] goes the furthest in emphasizing the collective over individual dimension when he presents a rationale for what he calls "selves-directed learning" (p. 251). Garrison [13] claims that the individual does not construct meaning in isolation; to take responsibility of your own learning does not necessarily mean to make decisions in isolation. Garrison ([13], p. 18) defines self-directed learning as "an approach where learners are motivated to assume personal responsibility and collaborative control of the cognitive (self-monitoring) and contextual (self-management) processes in constructing and confirming meaningful and worthwhile learning outcomes". He states that meaningfulness and worthwhileness reflect the cognitive and social perspectives of an educational experience. This understanding of self-direction is a "collaborative constructivist" perspective, according to Garrison. "A collaborative perspective has the individual taking responsibility for constructing meaning including the participation of others in confirming worthwhile knowledge" ([13], p. 19).

One of Knowles's assumptions about adult learners is that their self-concept moves from one of being a dependent personality towards being a self-directed human being $[7,18]$. Knowles ([8], p. 19) does not emphasize interdependent and collaborative aspects of self-directed learning in his definition:

In its broadest meaning, self-directed learning describes a process by which individuals take the initiative, with or without the assistance of others, in diagnosing their learning needs, formulating learning goals, identifying human and 
material resources for learning, choosing and implementing appropriate learning strategies, and evaluating learning outcomes.

The opposite of self-directed learning is what Knowles calls teacher-directed learning, which is based on what is often labelled "pedagogy," while self-directed learning is based on "andragogy". According to Knowles, self-directed and teacher-directed learning are grounded on two different sets of assumptions, andragogical and pedagogical, respectively. A self-directed learner has a self-concept of a nondependent person. According to Knowles, pedagogy is traditionally considered as transfer of information and that outer influences determine the learning outcome ([19], p. 83). The learner's role is dependency, and the teacher is responsible for learning to take place. The learner's experience is of little importance. From an andragogical point of view, the learner moves toward increasing self-directedness, and the teacher's role is to encourage this increasing selfdirectedness. The learner's experiences become an increasing source for learning.

The concept of self-directed learning appeared at about the same time as Knowles's andragogy [7, 18]. Both selfdirected learning and andragogy are attempts to define adult education as a unique field of practice and differentiate the field from learning in general and childhood education in particular [19]. "Until the mid-twentieth century, adult educators relied on research in psychology and educational psychology for an understanding of adult learning," Merriam ([19], p. 4) concludes. It should be mentioned that as early as the 1920s, Rosenstock-Huessy used the andragogy concept to describe a new direction for adult learning. According to him, "Andragogy represents an important break with mere pedagogy and demagogy" [20-22]. To Rosenstock-Huessy, andragogy was a new kind of teaching, aimed at solving social problems and moving towards a better future ([22], p. 15). The adults' sensibility for the spirit of the age should be developed, and adults should be motivated to take action with the purpose of improving society. Moreover, Rosenstock-Huessy was one of Lindeman's greatest inspirers [22]. Lindeman was one of Knowles's greatest inspirers ([23], p. 80). So, there is a link between those three great contributors to the field of adult education and learning.

Commenting on Knowles [8], Pratt [24] describes Knowles's view on self-directed learning as an ideology of technique. He "sets out, in formulaic terms, how it has to be performed, directed self-directed learning, so to speak," Pratt declares. Chené [25] also warns against reducing selfdirection to comprise control of learning techniques only. In her opinion, to be resourceful and independent is not similar to being self-directed. It also requires awareness about the learning process and the possibility to make critical judgement on the basis of knowledge of the limit for possible choices. Therefore, the development of judgement ability is central. So self-direction is not only a question of "technique"; normative sides and aspects of knowledge are essential as well. It is possible to direct your own learning as technically competent without questioning the underlying norms. In the future, we ought to differentiate between the techniques for self-direction and the inner change of consciousness which we might call self-directed learning [15]. However, in his opinion, there is also a risk in emphasizing a great extent of control of the purpose and intention of the learning activities. Even if this is one important premise of self-directed learning, adults may be tempted to enter into an intellectual journey without knowing the aim of this journey, he asserts.

\subsection{Dimensions of Self-Directed Learning. Different per-} ceptions of self-directed learning can also be expressed as dimensions, divided on the basis of different features or attributes of self-directed learning. Several authors have contributed to this sort of classification.

Candy [26] uses two interacting dimensions in his definition of self-directed learning. One dimension is control within an institutional setting. One extreme of this dimension is the educator's full control of how the content is to be presented, what is to be studied, and what outcomes are expected. The opposite extreme is where the learner has full control over the learning experience. According to Candy, self-direction is an outcome of the interaction between a person and the environment. In his opinion, the focus on autonomy has limited the understanding of self-directed learning, leading to a mismatch when implementing it in an educational setting. If the learner lacks appropriate skills or self-confidence for self-directed learning, the opportunity to be autonomous is purposeless.

The other dimension in Candy's [26] definition is learner control in situations outside the formal institutional setting. In this dimension, the student makes the decisions about learning, such as what is to be learned, what are the learning activities, when and where will the learning activities take place, and how to evaluate the learning outcomes. Candy refers to this as "autodidaxy".

Brockett and Hiemstra [27] also use two dimensions in their definition. The first one is personal responsibility in the teaching-learning process. In this dimension, self-direction is a process where learners assume primary responsibility for planning, implementing, and evaluating the learning process.

The second dimension is personal responsibility in one's own thoughts and actions. In this dimension, self-directed learning is referred to as a goal. Learners may have control over their response to a situation even if they do not have control over the actual circumstances in which they need to react $[27,28]$.

There are many other definitions of self-directed learning. Dehnad et al. [29] conclude that there is no consistency in defining it. Some researchers apply Knowles's [8] definition, others use the definition of Abdullah [30], and others use different descriptions suggesting that the literature lacks a conceptual framework. This is part of the terminological confusion Van der Walt points to, which leads to communication difficulties when discussing self-directed learning ([12], p. 16). Abdullah [30] states that there may be slight variations in how different educators define it, but a survey of the literature on the subject identifies several tenets 
that are central to the concept. Self-directed learning views learners as responsible owners and managers of their own learning process [30].

Long [28] identifies three dimensions of self-directed learning: sociological, pedagogical, and psychological.

The sociological dimension emphasizes the social isolation of the learner, claiming that self-directed learning is usually associated with social independence in the learning situation. Then, learning will take place independently of others in a socially isolated situation ([31], p. 331). Webbased learning might be an example of self-directed learning in a sociological sense. A main point is that the learning activities should not be determined by one or another social authority. This is the autonomous, independent individual undertaking learning for personal growth [16].

The pedagogical dimension implies that the pedagogical "procedures" are performed by the learner. Whether the learning can be defined as self-directed depends on the degree of freedom when it comes to determining learning goals and influence on planning, implementation, and evaluation, as well as other things associated with the pedagogical parts of learning activities. Seen from the pedagogy side, self-direction can be learned and developed and is considered a goal. This means that self-directed learning can take place without social isolation. Self-directed learning can take place in groups as well or in cooperation with institutions or others. Neither social isolation nor total independence is necessary.

Psychological self-direction is about the personal characteristics of the learner, including focus on necessary abilities and skills to carry out self-directed learning. Psychologically, self-directed learning is a question of to what extent the learner maintains an active control of the learning process. The mental activities are in focus. The most important are not the external factors but the inner psychological control in the learning situation. Here, Long underlines the importance of the individual experiencing a personal control of the learning situation, despite external factors. Long [28] argues that psychological self-directedness is necessary for self-directed learning, meaning that the learner must take the responsibility for a critical judgement of the content. In his view, when the learner is not in active control of the learning process, it is not psychological selfdirectedness.

"A meaningful or emancipatory learning experience must not deny the integrity and freedom of the individual. At the same time, adult educators must not ignore the potential of others to support the individual in acquiring and applying useful and worthwhile knowledge" ([13], p. 147).

Long [28] claims that much of the discussion on dimensions of self-directed learning has focused on the sociological and pedagogical and that the psychological dimension is generally ignored. His focus is on the interaction of two dimensions, namely, pedagogical and psychological control. Pedagogical control, as he defines, is the degree of freedom to determine learning goals, seek resources, and set the mode of evaluation. Psychological control, as he defines, is the degree of willingness to maintain active control of the learning process. When these two forms of control are equal or the psychological control exceeds pedagogical control, he defines the situation as a self-directed learning condition.

\subsection{Self-Directed and Self-Regulated Learning.} "Self-regulated learning and self-directed learning: why don't some neighbours communicate?" This question is raised by Cosnefroy and Carré [32]; seminal definitions of both terms show a great deal of notional overlap. Loyens et al. [33] state that, semantically speaking, there is little doubt that self-directed learning and self-regulated learning are close neighbours and can be considered as synonymous. They conclude that even scholars in educational psychology have suggested that the terms have often been used interchangeably in the literature. With no doubt, at first sight, self-directed learning and self-regulated learning seem highly similar ([34], p. 417), and several recent articles use both notions indifferently as if they were accepted synonyms $[35,36]$.

Loyens et al. [33] describe it this way:

Clearly, both SDL and SRL carry an element of student control. However, the degree of control the learner has, specifically at the beginning of the learning process when the learning task is defined, differs in SDL and SRL. In SDL, the learning task is always defined by the learner. A self-directed learner should be able to define what needs to be learned. In SRL, the learning task can be generated by the teacher. In this sense, SDL can encompass SRL, but the opposite does not hold (p. 418).

Makonye [37] compares self-directed learning (SDL), self-regulated learning (SRL), and problem-based learning (PBL) and concludes that they have similarities referring to the greater responsibilities of the students in learning situations. Students assume varying levels of control over the learning situation. Makonye claims that the differences mainly relate to the amount of freedom of the learners in a learning setting.

3.3. Theoretical Framework. There is no consistent theoretical perspective underlying the study of self-direction, according to Candy [10]. However, self-directed learning is evidently grounded in humanistic assumptions. The humanist philosophy was an inspiration for adult educators looking for an alternative to the traditions of pedagogy and influenced the conceptualizing of adult education [38].

Humanistic theory regards each human being as unique, and this uniqueness calls for an individualized approach to learning. It regards self-direction as the process, as well as the end product of learning. The motivation to learning is intrinsic and emanates from the learner. Humanistic theory has as a purpose to produce individuals who have the potential for self-actualization and are self-directed and internally motivated ([39], p. 1562). Self-actualization is to fulfill your potentiality and is the highest level of human 
growth. From this point of view, an individual is seen as the best judge of whether his or her learning meets his or her needs and interests. The teacher is a facilitator or a partner in the learning process.

However, the concept of humanism is multifaceted and ambiguous. There are different tendencies that are partly in conflict with each other. The humanism mentioned above should be called romantic humanism, which is influenced to a great extent by humanistic psychology in the 1960s, with Abraham Maslow and Carl Rogers as central representatives $[23,40]$. This is also where Knowles's andragogy belongs. Romantic humanism emphasizes to a great extent that the human being has the power for personal development. This is unlike traditional humanism, which considers the human being as an individual with a need to be shaped from the outside, having a need for some sort of upbringing. Some cues for romantic humanism are freedom, dignity, selfawareness, self-realization, and the development of the whole human potential.

Arsic [41] discusses three educational theorists in relation to self-directed learning. In addition to the progressivist John Dewey, Jean-Jacques Rousseau, and Alexander Neill are also described as the real forefathers of self-directed learning. "Combining the strong ideas of discovery from Rousseau, cooperation and socialization from Dewey, and self-management and democracy from Neill makes for an environment that is conducive to the SDL" ([41], p. 9). Arsic also discusses two theories of psychology in relation to selfdirected learning. The first one is Piaget's theory of cognitive development, and the other one is Vygotsky's sociocultural theory of cognitive development. Arsic [41] argues that the relation of these theories to self-directed learning is obvious. With reference to Piaget, curiosity is the key to acquiring knowledge and to learn new things in a meaningful way. Piaget's constructivist theory of development is the idea that more advanced forms of cognition are constructed by the individual through a process of "self-directed" or "selfregulated" activity, according to Kuhn and Ho [42]. With reference to Vygotsky and the concept of scaffolding, Arsic [41] accentuates the role of the teacher in promoting an environment conducive to self-directed learning.

From the sociological side, Arsic particularly calls attention to critical pedagogy, with focus on awareness and conscientisation. Garrison ([14], p. 138) states that critical thinking is not purely a cognitive or reflective process because the use of "critical" changes the meaning. Critical means to judge and not take things for granted. To Mezirow [43], a key dimension of self-directedness is critical awareness of meaning and self-knowledge. He states that a critical and self-reflective attitude is a fundamental element of self-direction and is necessary when it comes to personal responsibility for your opinions and actions.

\section{Why Self-Directed Learning?}

Self-directed learning expresses a view of learning that stands opposed to a more traditional content-centered practice where the teacher is the bearer of knowledge and the learner's experience is of minor interest. For some, this may be the reason for adapting self-directed learning and, to others, a reason for rejecting it. Moreover, there seems to be an increasing need of self-directed learners in society and work life. That alone should be a reasonable argument for increased focus on this approach to learning. In the following, some findings and statements on the benefits of selfdirected learning are reported.

Knowles [8] maintains that there is convincing evidence that people who take the initiative in learning learn more and learn better than people who are passively being taught. Self-initiated learners have a greater and more purposeful motivation and tend to apply, to a greater extent, the knowledge they have learned in their daily lives. Suanmali [44] refers to a study indicating that self-initiated and responsible action proved far more effective than guided action.

An interesting study concerning students' feeling about themselves as self-directed learners as compared to the teacher-centred learners demonstrated that there is a significant difference regarding the feeling of the two groups [44]. The self-directed learners feel good about themselves as learners. They feel they can successfully make decisions that are related to their learning needs, and they see themselves developing autonomy with respect to these decisions. Furthermore, they are much more likely to feel successful as learners than the teacher-directed counterparts.

Suanmali [44] states that, in the maturing process, many components are involved, one of which is the self-directing capability, that is, the greater the capacity for becoming a self-directing person is, the more tendency there is to be a mature person. This quality of being mature characterizes and differentiates adults from children.

Brockett [45] suggests that older adults who learn to be more self-directed have the potential to increase independence and life satisfaction. Grover et al. [46] state that regardless of their reason for participation, engagement in selfdirected learning has been positively related to higher satisfaction of life in older adults specifically. The literature on the benefits of self-directed learning among older adults, in particular, is not as well-established as outcomes mature adults experience from learning generally, but there is evidence that a positive relationship exists [46].

Jenkins [47] carried out a longitudinal study on the relationship between well-being and participation in learning by older adults. His findings show that informal learning, in this case, through activities such as education, music and arts groups, and exercise classes, can enhance the well-being. However, his research also revealed that this was truer for those with some higher education than for those who had little or none.

Moreover, a central argument for self-directed learning is that it has a potential to improve the quality of learning outcomes both in the short and in the long term [13], and it is also an essential skill to be acquired for the promotion of life-long learning [48]. Kuhn and Ho [42] also suggest that self-direction is of potential importance for the enhancement of cognitive development. However, they say that much more research is required to make such generalizations with confidence. 
Another argument for increased focus on self-directed learning is societal and technological changes worldwide. The world has changed vastly since the term self-directed learning appeared half a century ago. The rapid rate of political, social, and technological change with which we are currently confronted has increased rather than diminished the need for self-directed citizens $[10,49]$. The technological development at the workplace and in society, as a whole, requires unique skills and abilities.

The workplace is of growing importance for learning, leading to an increasing need of self-directed learners, mainly because of more responsive and cost-effective learning infrastructures [50]. According to Guglielmino and Guglielmino [51], the self-directed learner is the cornerstone of the learning organization. Skills and knowledge are not durable; continuous learning is required. Organizations should be aware of not making barriers for or discouraging self-directed learners. Rana et al. [52] cite Marquardt's ([53], p. 19) understanding of a learning organization as "an organization which learns powerfully and collectively and is continually transforming itself to better collect, manage, and use knowledge for corporate success". To develop the knowledge base of the organization, the individual members of the organization should have the capacity to be self-directed learners. This is of considerable importance for the development of a learning organization, as well as the development of employees at all levels [52].

Another social and political issue where self-directed learning may have a potential role is how to develop democratic citizenship skills. According to Manning [49], "One potential characteristic of self-directed learners is striving for the democratic ideal," and "people whose lives are affected by a decision must be a part of the process of arriving at that decision."

Critical theorists like Freire [54] and Mezirow [43] also make sense of self-directed learning because it clears the way for critical awareness. Gelpi [55] states that self-directed learning, from a social point of view, means a danger to oppressors because it makes it more difficult for the oppressive power to keep control. Nevertheless, Rubenson and Borgstrøm [56] conclude that the connection between selfdirected learning and progressive social change is more complicated than commonly assumed.

\section{Self-Direction Ability: Maturation or Learning?}

Whether self-direction is natural or learned is of considerable importance to how this learning approach should be treated in a learning situation. Is the ability to self-direction essentially innate or is it a skill that must be learned? Are learners self-directed because they are adults or is it a skill that must be learned? These are central issues in this context.

According to Knowles [7, 18], adults have a deep psychological need of being perceived by others as self-directed. However, research shows that adults are not necessarily naturally self-directed. Brookfield ([15], p. 121) claims that "there has been a too ready acceptance of the idea that a drive towards self-directedness is an innate characteristic of adulthood, readily apparent in all teaching-learning transactions". Seen from a prescriptive point of view, self-direction is a goal that should be pursued in learning situations and becomes a sort of primary goal in adult education to help make adults more self-directed. Self-directing ability refers to how adults ought to be, but it is not a general description of adults.

For self-directed learners to be effective at identifying and initiating learning needs and goals, as well as identifying and employing appropriate resources and strategies, as suggested by Knowles's definition, they must learn how to learn [57]. A self-educator needs to know how to learn effectively ([44], p. 99). Thus, the role of an educator is to assist the learners so that they are able to meet the demands and requirements of these learning situations. Program designers and adult education agencies or institutions also need to be involved in this effort.

\section{What Affects the Tendency to Self- Directed Learning?}

Tough $[4,5]$ concluded that adults spend much time on what he called learning projects. Still, it is likely to believe that the tendency to self-direction is not equally predominant in all situations or in all social and cultural contexts. Brockett [45] found that adults' tendency towards self-direction is influenced by factors such as the educational level, quality of life, and independence, with the educational level as the most important. Chronological age is of little or no importance, he stated. However, conflicting findings exist, for instance, Hutto's [58] study, which showed that age and gender were significantly related to self-directed learning. Females and respondents in the age category 46-55 scored significantly higher than males and respondents in the three other age groups. This shows the difficulty in drawing a definite answer to this issue.

Is it possible to assess the degree of readiness for selfdirected learning? Guglielmino [59] developed an instrument for the purpose of assessing the degree of readiness for self-directed learning perceived by individuals. This instrument named the Self-Directed Learning Readiness Scale (SDLRS) is based on eight factors which individuals should respond to: openness to learning opportunities, self-concept as an effective learner, initiative and independence in learning, informed acceptance of responsibility for one's own learning, love for learning, creativity, future orientation, and the ability to use basic study and problem-solving skills.

Adults' propensity to self-directed learning can also be related to a strong need of merely seeing and learning things that go with their own self-concept, according to Moxnes [60]. It is easier to learn new things about ourselves if we just add it to prior knowledge. So, from one point of view, motivation for self-directed learning can arise out of a desire not to learn anything new. New knowledge is meant to be uncritically linked to "old knowledge". In other words, new knowledge is okay if it is not contrary to what you know already. 
6.1. Sociodemographic Factors. The tendency to self-direction is not only affected by personal characteristics of the learner. Studies referred to in the following show that sociodemographic factors such as nationality, ethnicity, social class, employment status, and local culture are important factors in this context.

One of these studies is carried out by Adenuga [57]. Results from his study suggest that sociodemographic and cultural factors play a significant role in a person's preparedness to assume major control of one's learning. He brings up demographic variables, such as nationality and degree program, as the most predictive factors regarding readiness for self-directed learning. He also asserts that the cross-cultural validity of Guglielmino's [59] SDLRS instrument is far from established. In general, there is also a dearth of research on self-directed learning about adults in developing countries, in his opinion.

Brookfield [61] criticizes the Eurocentric perspective. Rational, autonomous, critical thought are taken for granted as values worth aspiring to. "Central to this racialization of adult education is the fact that it is deemed so obvious as to need no justification. Consequently, the racialization of adult education theorizing, the way it is viewed through the lens of Eurocentric Whiteness, with Whiteness regarded as the positively valued, unspoken norm, is rarely commented on" ([61], p. 499). The common understanding of what are normal educational processes and adult learning activities, such as self-directed learning, transformative learning, and critical reflection, are based on the enlightenment rationality, according to Brookfield. The emphasis is on the rational, self-propelled individual searching for wisdom, and the literature keeping up these norms is mainly produced by white Americans or Europeans "steeped in Eurocentrism" ([61], pp. 516-517).

Nasri and Mansor [62], in their study of Malaysian teacher educators, have found that local culture is the single most important influence on self-directed learning when this culture has influenced the learner's behaviour and ways of thinking.

$\mathrm{Na}$ et al. [63] have observed differences in sociocultural contexts with regard to social class. They have observed that working-class individuals are more likely to adopt the interdependent self-view, while middle-class individuals are more likely to adopt the independent self-view ([63], p. 2). The latter fits best with self-direction. The study also shows that working-class contexts facilitate the development of a different type of self-concept. Working-class individuals are flexible and sensitive to external factors, while middle-class individuals often take occupational positions that allow them to maintain or even strengthen their independence (or self-direction) at work ([63], p. 7).

Is self-directed learning a middle-class activity? A consistent feature of the groups studied relative to self-directed learning is that they have a middle-class feature [15]. The education level has been above average, so the groups are not representative of the population. Brookfield doubts that the behaviour of these groups with regard to self-directed learning can be valid for other social classes and ethnic groups. It is not reasonable referring to adults' tendency to self-directed learning when the reference basis is the American middle class, he states; working-class individuals would perhaps show a completely different behaviour.

The previous paragraphs tell me that self-directed learning is not a theory of universal application. The sociocultural aspect should be credited considerable importance. The problem is not necessarily that self-directed learning is an unknown approach to learning. The reason may, as well, be certain cultural or social conditions making self-directed learning unfamiliar and undesirable.

6.2. Learning Styles. Much critique has been raised against learning styles. Newton and Miah [64] state that there is no evidence to support the use of learning styles, but also note that the general belief in this approach is high. Many educators claim that the use of learning styles will result in improved learning ([64], p. 1). Newton and Miah conclude that there is a mismatch between empirical evidence and practice, and this has lead to tension and controversy.

An argument for classifying individuals in different learning styles is the belief that this will improve learning by using methods that match the individual's learning style. Newton and Miah ([64], p. 8) claim that instead of focusing on learning styles, it may be more productive to focus on the use of teaching and development activities which are proved to be effective. LeBlanc ([65], p. 34) concludes that instead of promoting learning styles, educators should instruct learners on the intentional use of learning strategies. Smith, Sekar, and Townsend ([66], p. 411) refer to research that raises doubts about whether matching of learning style and instructional style is preferable. For each research study supporting the matching hypothesis, there is a study rejecting it, they state. As Robotham ([67], p. 3) states, "a truly proficient learner is not someone who demonstrates capability within a narrow band of activities, as defined by a particular learning style, but rather someone who demonstrates the ability to select an appropriate learning style from a range of styles, according to the demands of the situation and their own learning capability. This will be particularly true in the work environment, where the inherent flexibility to be able to respond to the specific needs of different situations is clearly a desirable personal attribute." In his opinion, this ability to select actively from a personal style or skills portfolio is part of what can be termed self-directed learning ([67], p. 3).

Nevertheless, I will include some theory on learning styles because it is an aspect of self-directed learning that some authors have attached importance to. Adenuga [57] is one of them. He found that learning styles seem to be the next best predictors of readiness for self-direction. For that reason, teachers should be aware of individual learning styles and be able to and willing to adapt the learning situation to the learner's readiness [57, 67]. Gokalp [68] claims that instructors and learners need to better understand and appreciate individual differences and how they affect the learning process. A simple awareness of differences in student learning styles is vital for educators to aid the 
learning process. Effective instruction reaches out to all students, not just those with one particular learning style ([68], p. 628). "The first step in attempting to develop in individuals the ability to self-direct is to assess the current level of self-direction that an individual is able to exhibit," Robotham ([67], p. 5) states. When the current stage of selfdirection is established, it is easier to prepare for meaningful learning.

Kolb's learning styles are among the best known. His four learning style types are as follows $([69,70]$, p. 48):

The diverger combines concrete experience and reflective observation.

The assimilator combines abstract conceptualization with reflective observation.

The converger combines abstract conceptualization with active experimentation.

The accommodator combines active experimentation with concrete experience.

These terms were later changed to the diverging style, the assimilating style, the converging style, and the accommodating style, as a response to the criticism that people tend to treat their learning style as static ([71], p. 61).

Kolb [69] indicated that self-directed learning is more closely correlated in the direction of active experimentation. The learner's experience and interaction with the environment are the common features of Kolb's model and the selfdirected learning process [72]. Adenuga [57] concluded differently. He found that a learner who prefers both active experimentation and abstract conceptualization, which is the learning style of a converger (the converging style), tends to be strong in self-directed learning readiness. He also claims that "effective learners are those who effectively combine feeling and action, activity with reflectivity, thinking, and doing, cognition, and affect" ([57], pp. 156-157). Theil [72] suggested that self-directed learning may be more closely related to an accommodator learning style than with the other three styles. Golightly [73] investigated the relationship between learning style preferences and self-directed learning of preservice teachers. He found that most of them preferred the converging and assimilation learning. However, no relationship was found between learning style preferences and self-directed learning in his study. Golightly's conclusion is that self-directed learning is not related to any particular one of Kolb's learning styles. The findings referred to display different conclusions regarding the interrelationship between selfdirected learning and learning styles.

Coffield et. al. [71] critically reviewed the literature on 13 of the most influential models of learning styles, Kolb's model included. They found some overlap among the concepts used, but no direct or easy comparability between approaches; there is no "core" technical vocabulary, they concluded (p. 136). They refer to a great number of dichotomies in the literature of learning styles, e.g., assimilators versus accommodators and convergers versus divergers, contributing to the dissemination of conceptual confusion, they state (p. 136). This makes it difficult to compare the approaches. "In addition, the complexity of the learning styles field and the lack of an overarching synthesis of the models or of dialogue between the leading proponents of individual models lead to the impression of a research area that have become fragmented, isolated, and ineffective" ( $p$. 136).

\section{Is Self-Direction Situational?}

Previously, attention was directed to what affects the tendency to self-directed learning. In the following, the focus is on the situational aspect. The same individual may have a different view of self-directed learning in different situations. The ability and will to self-direction is not an inherent quality that is expressed similarly in all situations. Therefore, the situational aspect is dealt with separately. Grow's stages of self-direction are also included to call attention to the situational aspect of this theory.

Self-direction cannot be perceived as a universal characteristic of being an adult but rather a situational characteristic. Adults, similar to children, are able to self-direct in some situations but not in all [74]. This is Knowles's conclusion as well; the ability to self-direct is independent of age but dependent of situation. However, he warns against keeping the learners dependent long after they are able to direct themselves.

Pratt [24] also accentuates that self-direction and dependence must be seen in relation to context. If, for instance, goal and content are externally determined beforehand, full self-direction will be difficult. So, self-direction should not be considered a universal characteristic of adult life.

In andragogy, it is a matter of course that characteristics and behaviour are independent of context ([75], p. 162). The fact that biologically, juridically, psychologically, and socially an adult has a certain set of characteristics does not mean that these characteristics are brought into the educational situation. In a way, self-directed learning becomes wishful thinking in this connection since it appears that many adults lack both inner motivation and sense of responsibility. Obviously, the andragogical definition of adults is based on assumptions and expectations of ideal conditions rather than how they actually are.

The unmotivated adults with poor self-confidence and negative attitudes to learning, not being able to take responsibility for their own studies, and who, of different reasons, are not able to accept the offers given give rise to a different picture. The discrepancy between the ideal and the real ought to bring about a desire to a context-dependent educational theory based on individual differences and not based on a socially constructed and homogeneous belonging ([75], p. 166).

The andragogical principles work in certain learning situations, but adapted to a school practice, they can lead to confused students. The possible expectations some students have to a traditional school with a clearly structured activity and an authoritative teacher imparting knowledge do not 
come up to their expectations. These expectations also imply leaving the responsibility to the teacher, and when that is not the case, it may be a potential reason for many study intermissions. Adult education teachers working from the andragogical principles do not consider themselves as simply assuming responsibility for dissemination of knowledge but work as guides and resources ([75], p. 165).

In adult learning theory, personal responsibility and natural motivated students are fundamental concepts, and the teachers also express such expectations for their students. However, in the school situation, the adult does not necessarily act in accordance with these expectations in a voluntary school. The student has some deficiencies that sometimes make it difficult to handle an educational situation. Since students acting in accordance with the andragogical model may be in minority, the teacher must be aware of this ([75], p. 165).

7.1. Grow's Stages of Self-Direction. The situational aspect of self-directed learning is incorporated in Grow's [76] stages of self-direction. He makes visible the gradual progress toward self-direction. According to Grow [76], self-direction is both a personal attribute that develops in stages and a situational response. The degree of self-direction can be a response to a specific learning situation, but it is also an ability that is possible to learn. Therefore, the goal of the educational process must be to produce self-directed learners.

Students have varying ability to relate to teaching that requires self-direction. There may be a bad coherence between the teacher's role and style and the students' stage of self-direction. The teacher must adapt to the students' stage of self-direction and allow them to be more self-directed in their learning. Therefore, good teaching is situational by nature and must be an integrated part of teaching. Selfdirected learning readiness is situational and may also be task specific, according to Grow [76]; few learners are equally motivated towards all subjects, and learners have varying abilities to respond to teaching that requires them to be self-directed. The teaching must be individualized to fit the learners' degree of self-direction and allow them to be more self-directed in their learning. Problems arise when the teaching style does not match the learner's degree of selfdirection. Grow [76] has created a self-directed learning model accounting for different stages of self-direction.

In stage 1 , there are learners with little degree of selfdirection. They are dependent learners, and the learning is teacher-centred. The teacher should be an authority and a coach and should avoid giving choices. The teacher's communication is mainly one-way, and focus should be on the subject, not on the learners. Students in stage 1 cannot be considered self-directed learners. They are learners who are dependent on their teachers ([70], pp. 20-21).

Learners in stage 2 are moderately self-directed. They are interested and interestable, as Grow puts it, and the teacher should be a motivator and guide. The learners respond to motivational techniques and are willing to do assignments they can see the purpose of. The learners are still largely ignorant of the subject taught. The communication in this stage is two-way, and the learners communicate their responses and interests.

Stage 3 is a transitional stage towards self-direction. The teacher is a facilitator, and the learners are involved in discussions facilitated by the teacher, who participates as an equal. There are seminars and group projects as well. According to Grow, the learners have skills and knowledge and see themselves as participants in their own education. They are ready to explore a subject if they have a good guide, and some are on their own. They will benefit from learning more about how they learn, for example, the conscious use of learning strategies. As stage 3 learners become more selfdirected, the teacher will help them structure the transition towards independence, Grow [76] states.

Stage 4 learners are highly self-directed, and the teacher is a consultant and delegator. The learners can set their own goals and standards with or without help from experts. They are willing to take responsibility for their learning, direction, and productivity. Now, the progression is complete from the subject-matter focus of the earliest stages to the learnerfocus of stage 4. According to Grow, the teacher's role in stage 4 is not to teach the subject matter but to cultivate the learner's ability to learn. The teacher gradually reduces both two-way communication and external reinforcement, and the learner may not need a teacher at all [76].

\section{The Paradox of Choice}

"Choice is one of the hallmarks of self-direction in learning and in life", Brockett ([77], p. 27) states; choice is liberating but can also be restricting and even debilitating. Still, it seems clear that today's extensive access to information is overwhelming and may lead to problems. Schwartz ([78], pp. 80-81) notes that "when self-determination is carried to extremes, it leads not to freedom of choice but to tyranny of choice." Learners need some sort of parameters on what they perceive to be viable choices; otherwise, they can become overwhelmed by the options, and the likelihood of making a good choice may be reduced [77]. This can lead to choice overload, as he calls it, with a negative impact on the sense of well-being and life satisfaction ([77], p. 32). Hiemstra [79] focuses on the Internet as a helpful learning resource but also warns against information overload. The bombardment of information may be daunting.

Self-directed learning should help identify and recognise the range of choices available. Today, it needs to be more about helping people to focus, determine priorities, and identify parameters for decisions. Brockett [77] claims that the paradox of choice is very relevant to self-directed learning. He focuses on two ideas for helping self-directed learners; first, helping them make good decisions, and second, recognising that there are times when choosing not to learn is a viable option (p. 31).

\section{Conclusions}

Self-directed learning is one important piece of the mosaic forming the knowledge base of adult learning [19]. This 
article discusses a number of factors affecting the propensity and ability to self-direct.

As a self-directed learner, you must have minimum control over the time, pace, and place for learning. However, considering all sides of the matter, an obvious statement is that self-directed learning is not primarily about control of learning techniques. Control of the learning situation is only one element of self-directed learning. Other elements are the ability and willingness to reflect, critical judgement, and necessary knowledge of alternatives.

Adults are not self-directed because they are adults, but they are, according to Knowles [7], in need of being looked upon as self-directed because they are adults because it affects their self-concept. The individual's ability to selfdirect is of great importance to the society, working life, and self-development. Consequently, the teacher must take this into account and adapt the learning situation to varying stages of self-directing ability. To create good learning situations, the teacher must be conscious of the great differences existing with regard to ability of and will to selfdirection.

\section{Data Availability}

No data were used in this study.

\section{Conflicts of Interest}

The authors declare that they have no conflicts of interest.

\section{References}

[1] S. Tøsse, "Frå folkeopplysning til vaksenopplæring [From popular education to adult education," The Norwegian University of Science and Technology, Trondheim, Norway, 2005.

[2] C. O. Houle, The Inquiring Mind, University of Wisconsin Press, WI, USA, 1961.

[3] R. G. Brockett and R. C. Donaghy, "Beyond the inquiring mind: cyril houle's connection to self-directed learning," 2005.

[4] A. Tough, Learning without a Teacher: A Study of Tasks and Assistance during Adult Self-Teaching, Ontario Institute for Studies in Education, Toronto, ON, USA, 1967.

[5] A. Tough, The Adults's Learning Projects: A Fresh Approach to Theory and Practice in Adult Learning, Ontario Institute for Studies in Education, Toronto, ON, USA, 1971.

[6] A. Tough, "Major learning efforts: recent research and future directions," Adult Education, vol. 28, no. 4, 1978.

[7] M. S. Knowles, The Modern Practice of Adult Education: Andragogy versus Pedagogy, Association Press, New York, NY, USA, 1970.

[8] M. S. Knowles, Self-directed Learning: A Guide for Learners and Teachers, Association Press, New York, NY, USA, 1975.

[9] E. C. Lindeman, The Meaning of Adult Education, Harvest House, Montreal, USA, 1926.

[10] P. C. Candy, "Key issues for research in self-directed learning," Studies in Continuing Education, vol. 10, no. 2, pp. 104-124, 1988.

[11] S. Kerka, Self-directed Learning: Myths and Realities, ERIC Clearinghouse on Adult, Career, and Vocational Education, Columbus, OH, USA, 1994.
[12] J. L. Van der Walt, “The term "Self-Directed learning”-back to Knowles, or another way to forge ahead?" Journal of Research on Christian Education, vol. 28, no. 1, pp. 1-20, 2019.

[13] D. R. Garrison, "Self-directed learning: toward a comprehensive model," Adult Education Quarterly, vol. 48, no. 1, pp. 18-33, 1997.

[14] D. R. Garrison, "Critical thinking and self-directed learning in adult education: an analysis of responsibility and control issues," Adult Education Quarterly, vol. 42, no. 3, pp. 136-148, 1992.

[15] S. D. Brookfield, "Self-directed learning: a conceptual and methodological exploration," Studies in the Education of Adults, vol. 17, no. 1, 1985.

[16] S. B. Merriam and R. S. Caffarella, Learning in Adulthood, Jossey-Bass, San Francisco, CA, USA, 1999.

[17] D. O'Donnell, "Habermas, critical theory and selves-directed learning," Journal of European Industrial Training, vol. 23, no. 4/5, pp. 251-261, 1999.

[18] M. S. Knowles, The Modern Practice of Adult Education: From Pedagogy to Andragogy, Association Press, Chicago, IL, USA, 1980.

[19] S. B. Merriam, Andragogy and Self-Directed Learning: Pillars of Adult Learning Theory, New Directions for Adult and Continuing Education, Chicago, IL, USA, 2001.

[20] E. Rosenstock, Andragogik, Pass \& Garleb, Berlin, Germany, 1924.

[21] S. Loeng, "Eugen Rosenstock-Huessy-an andragogical pioneer," Studies in Continuing Education, vol. 35, no. 2, pp. 241-253, 2013.

[22] S. Loeng, "Various ways of understanding the concept of andragogy," Cogent Education, vol. 5, no. 1, pp. 1-33, 2018.

[23] S. Loeng, "Andragogy: a historical and professional review," Stjørdal: Loringsforlaget, vol. 35, 2010.

[24] D. D. Pratt, "Andragogy after twenty-five years," in An Update on Adult Learning Theory. New Directions for Adult and Continuing Education, S. B. Merriam, Ed., vol. 57, pp. 15-23, Jossey-Bass Publishers, San Francisco, CA, USA, 1993.

[25] A. Chené, "The concept of autonomy in adult education: a philosophical discussion," Adult Education Quarterly, vol. 34, no. $1,1983$.

[26] P. C. Candy, Self-direction for Lifelong Learning: A Comprehensive Guide to Theory and Practice, Jossey-Bass, San Francisco, CA, USA, 1991.

[27] R. G. Brockett and R. Hiemstra, Self-direction in Adult Learning: Perspectives on Theory, Research, and Practice, Routledge, New York, NY, USA, 1991.

[28] H. B. Long, "Self-directed learning: merging theory and practice," in Self-directed Learning Merging Theory and Practice, H. B. Long, Ed., Research Center for Continuing Professional and Higher Education of the University of Oklahoma, Oklahoma, USA, 1989.

[29] A. Dehnad, F. Afsharian, F. Hosseini, S. K. S. Arabshahi, and S. Bigdeli, "Pursuing a definition of self-directed learning in literature from 2000-2012," Procedia-Social and Behavioral Sciences, vol. 116, pp. 5184-5187, 2014.

[30] M. H. Abdullah, "Self-directed learning," ERIC Digest. ERIC Clearinghouse on Reading, English and Communication, ERIC Document Reproduction Service, New York, NY, USA, 2001.

[31] H. B. Long, "Psychological control in self-directed learning," International Journal of Lifelong Education, vol. 9, no. 4, 1990.

[32] L. Cosnefroy and P. Carré, "Self-regulated and self-directed learning: why don't some neighbors communicate?" International Journal of Self-Directed Learning, vol. 11, no. 2, pp. 1-12, 2014. 
[33] S. M. M. Loyens, J. Magda, and R. M. J. P. Rikers, "Self-directed learning in problem-based learning and its relationships with self-regulated learning," Educational Psychology Review, vol. 20, no. 4, pp. 411-427, 2008.

[34] H. Jossberger, S. Brand-Gruwel, H. Boshuizen, and M. Van De Wiel, "The challenge of self-directed and selfregulated learning in vocational education: a theoretical analysis and synthesis of requirements," Journal of Vocational Education \& Training, vol. 62, no. 4, pp. 415-440, 2010.

[35] B. Abar and E. Loken, "Self-regulated learning and self-directed study in a pre-college sample," Learning and Individual Differences, vol. 20, no. 1, pp. 25-29, 2010.

[36] G. M. Francom, "Teach me how to learn: principles for fostering students' self-directed learning skills," International Journal of Self-Directed Learning, vol. 7, no. 1, pp. 29-44, 2010.

[37] J. P. Makonye, “The enactment of problem-based approaches in pre-service mathematics and levels of performance of teacher students in problem projects," in Self-directed Learning Research: An Imperative for Transforming the Educational Landscape, E. Mentz and I. Oosthuizen, Eds., AOSI, Durbanville, South Africa, 2016.

[38] J. A. Draper, "The metamorphoses of "Andragogy"” Canadian Journal for the Study of Adult Education, vol. 12, no. 1, pp. 3-26, 1998.

[39] D. C. M. Taylor and H. Hamdy, "Adult learning theories: implications for learning and teaching in medical education: AMEE Guide no. 83," Medical Teacher, vol. 35, no. 11, pp. 1561-1572, 2013.

[40] K. Wain, Philosophy of Lifelong Education, Croom Helm, London, UK, 1987.

[41] A. Arsic, "Self-directed learning in an international Baccalaureate high school class," Concordia University, Montreal, Quebec, Canada, 2014.

[42] D. Kuhn and V. Ho, "Self-directed activity and cognitive development," Journal of Applied Developmental Psychology, vol. 1, no. 2, pp. 119-133, 1980.

[43] J. Mezirow, "A critical theory of self-directed learning," in Self-directed Learning: From Theory to Practice. New Directions for Continuing Education, S. Brookfield, Ed., Jossey-Bass, San Francisco, CA, USA, 1985.

[44] C. Suanmali, The Core Concepts of Andragogy, Columbia University Teachers College, San Francisco, CA, USA, 1981.

[45] R. G. Brockett, "The relationship between self-directed learning readiness and life satisfaction among older adults," Adult Education Quarterly, vol. 35, no. 4, pp. 210-219, 1985.

[46] K. S. Grover, M. T. Miller, and S. A. Porter, "Mature adult learners, self-directed learning practices, and quality of life," International Journal of Self-Directed Learning, vol. 14, no. 2, pp. 1-12, 2017.

[47] A. Jenkins and T. Mostafa, "The effects of learning on wellbeing for older adults in England," Ageing and Society, vol. 35, no. 10, pp. 2053-2070, 2015.

[48] F. Sze-yeng and R. M. R. Hussain, "Self-directed learning in a socioconstructivist learning environment," Procedia-Social and Behavioral Sciences, vol. 9, pp. 1913-1917, 2010.

[49] G. Manning, "Self-directed learning: a key component of adult learning theory," Journal of the Washington Institute of China Studies, vol. 2, no. 2, 2007.

[50] A. D. Ellinger, "The concept of self-directed learning and its implications for human resource development," Advances in Developing Human Resources, vol. 6, no. 2, pp. 158-177, 2004.

[51] P. J. Guglielmino and L. M. Guglielmino, "Moving toward a distributed learning model based on self-managed learning,"
S.A.M. Advanced Management Journal, vol. 66, no. 3, pp. 36-43, 2001.

[52] S. Rana, A. Ardichvili, and D. Polesello, "Promoting selfdirected learning in a learning organization: tools and practices," European Journal of Training and Development, vol. 40, no. 7, pp. 470-489, 2016.

[53] M. J. Marquardt, Building the Learning Organization: A Systems Approach to Quantum Improvement and Global Success, McGraw-Hill, New York, NY, USA, 1996.

[54] P. Freire, Pedagogy of the Oppressed, Continuum International Publishing Group Inc., New York, NY, USA, 1970.

[55] E. Gelpi, A Future for Lifelong Education, Vol. 13, Department of Adult and Higher Education, The University of Manchester, New York, NY, USA, 1979.

[56] K. Rubenson and L. Borgstrøm, Equality in the Context of Lifelong Education. Policy \& Research in Adult Education, International Colloquium at the Department of Adult Education, University of Nottingham, New York, NY, USA, 1981.

[57] B. O. Adenuga, Self-Directed Learning Readiness and Learning Style Preferences of Adult Learners, Iowa State University, Ames, Iowa, 1989.

[58] S. T. Hutto, The Relationships of Learning Style Balance and Learning Dimensions to Self-Directed Learning Propensity Among Adult Learners, The University of Southern Mississippi, The Aquila Digital Community, New York, NY, USA, 2009.

[59] L. M. Guglielmino, "Development of the self-directed learning readiness scale," Dissertation Abstracts International, vol. 38, no. 11, pp. 64-67, 1977.

[60] P. Moxnes, Loring Og Ressursutvikling I Arbeidsmiljøet [Learning and Resource Development in the Workplace Environment], Institutt for sosialvitenskap, Oslo, Norway, 1981.

[61] S. D. Brookfield, "Racializing the discourse of adult education," Harvard Educational Review, vol. 73, no. 4, 2003.

[62] N. M. Nasri and A. N. Mansor, "Teacher educators' perspectives on the sociocultural dimensions of self-directed learning," Creative Education, vol. 07, no. 18, pp. 2755-2773, 2016.

[63] J. Na, M. Y. Chan, J. Lodi-Smith, and D. C. Park, "Social-class differences in self-concept clarity and their implications for well-being," Journal of Health Psychology, vol. 23, no. 7, pp. 951-960, 2018.

[64] P. M. Newton and M. Miah, "Evidence-based higher education-is the learning styles "myth" important?" Frontiers in Psychology, vol. 8, no. 1-9, 2017.

[65] T. R. LeBlanc, "Learning styles: academic fact or urban myth? A recent review of the literature," Journal of College Academic Support Programs, vol. 1, no. 1, pp. 34-40, 2018.

[66] W. Smith, S. Sekar, and K. Townsend, "The impact of surface and reflective teaching and learning on student academic success," 2002.

[67] D. Robotham, "Self-directed learning," Journal of European Industrial Training, vol. 19, no. 7, pp. 3-7, 1995.

[68] M. Gokalp, "The effect of students' learning styles to their academic success," Creative Education, vol. 4, no. 10, pp. 627-632, 2013.

[69] D. A. Kolb, Experiential Learning: Experience as the Source of Learning and Development, Prentice-Hall, Englewood Cliffs, NJ, USA, 1984.

[70] J. B. Canipe, The Relationship between Self-Directed Learning and Learning Styles, The University of Tennessee, Knoxville, USA, 2001.

[71] F. Coffield, D. Moseley, E. Hall, and K. Ecclestone, "Learning styles and pedagogy in post-16 learning: a systematic and critical review," 2004. 
[72] J.-P. Theil, Successful Self-Directed Learners' Learning Styles, North Carolina State University, Department of Adult and Community Coll. Education, Raleigh, North Carolina, 1984.

[73] A. Golightly, "Do learning style preferences of preservice geography teachers matter in self-directed learning?" Journal of Geography, vol. 118, no. 4, pp. 143-156, 2019.

[74] G. Wichmann-Hansen, "Andragogiske antagelser om selvstyring og ansvarlighed [Andragogical assumptions on selfdirection and responsibility]," in Improving College and University Teaching, C. N. Jensen, Ed., vol. 32, 1999.

[75] A. Håkansson, Lärares Pedagogiska Arbete Inom Den Kommunala Vuxenutbildningen [Teachers' Educational Work in Municipal Adult Education], Högskolan Kristianstad, Institutionen För Beteendevetenskap, Kristianstad, Sweden, 2007.

[76] G. O. Grow, "Teaching learners to be self-directed," Adult Education Quarterly, vol. 41, no. 3, pp. 125-149, 1991.

[77] R. G. Brockett, "Self-directed learning and the paradox of choice," International Journal of Self-Directed Learning, vol. 3, no. 2, 2006.

[78] B. Schwartz, "Self-determination: the tyranny of freedom," American Psychologist, vol. 55, no. 1, pp. 79-88, 2000.

[79] R. Hiemstra, "Is the internet changing self-directed learning? Rural users provide some answers," International Journal of Self-Directed Learning, vol. 3, no. 2, 2006. 